\title{
1. The state and its infrastructure system
}

\section{INTRODUCTION}

At its core, the contemporary international system is based on the existence of and interaction between a set of territorially demarcated states (Agnew 1994). Within each of these territorially bounded spaces, the state - as a collection of centralised political institutions - is sovereign. This sovereignty within this internationally agreed geographic division is presumed to be mutually exclusive (Taylor 1995). Whilst the exclusivity of state territoriality has been increasingly challenged (see below), there can be little doubting that it remains a focal point within the operation of the contemporary international system. The desire of the state to sustain and maintain its territorial pre-eminence within its bounded space requires it to develop and implement territorial strategies that enable, enforce and/or legitimise its territoriality. This is suggestive that the primary objective of these territorial strategies is to enable territoriality through enhancing the welfare of its citizens via growth, improved security, socio-economic development, territorial cohesion, etc. (Taylor 1994). This emphasises - in the absence of coercion of its citizens - the link between territoriality and the legitimacy of the state as a territorial agent.

Integral to this link is the process of infrastructuring. This is defined as the act of creating and maintaining a territorial infrastructure system where infrastructure is commonly defined as 'built networks that enable flows over space' (Larkin 2013, p. 329), offering services that, at their core, are central to territorial functioning and to the operation of the agents within that space (Finger et al. 2005). These infrastructures are not just objects; they are dynamic systems that adapt to the tensions (both internal and external) that operate upon them. As will be argued throughout this formative chapter, the focus is not just the form of the system but also how its usage renders infrastructuring integral to such territorial strategies where the state - despite the progressive impact of 
privatisation and liberalisation of infrastructure systems - remains the primary body creating such structures.

This chapter provides the underlying framework for understanding the work within subsequent chapters. In so doing, the chapter examines the links between territoriality and the state's infrastructure system. Initially, the chapter will examine state territorial strategies and the role of infrastructuring within such strategies. Building upon these core themes, the chapter then moves on to examine the core underpinning framework of the book - the national infrastructure system (NIS) - in detail. This will address how the interacting components of the NIS enable state territorial strategies through what Johnson and Turner (2017) have termed the infrastructural mandate. Before the conclusions to the chapter are offered, the chapter examines the dynamics within an NIS to which they have to evolve if they are to be sustained as effective enablers of territorial strategy.

\section{STATE TERRITORIAL STRATEGIES AND INFRASTRUCTURING}

The link between infrastructure and territoriality is intimate, as infrastructure is part of the process whereby space is turned into territory. It is within the context of the state-based system that territoriality (that is the strategy through which a territory is realised) is commonly conceptualised $^{1}$ (see, for example, Taylor 1994). In this framework, state territory is that portion of the earth's surface that is subject to a single state's uncontested sovereignty (Hassan 2006). Giddens's (1985) conceptualisation of states as power containers frames territorial strategy as the means through which the state seeks to maintain its pre-eminent position within a territory (Johnston 2001). Integral to territorial strategy is the centralisation of the state's power (Mann 1984). Centralisation is important to this process as it enables the state to mobilise and concentrate resources. According to Taylor (2013), if you remove centralisation the state loses its autonomy and becomes just another 'interest'.

In these terms, the state exists as a territorialised set of centralised institutions whose function is to secure a set of defined outcomes within demarcated borders (Bourdieu and Farage 1994). This underpins the logic of state territoriality as 'a form of behaviour that uses a bounded space (a territory) as an instrument to secure a particular outcome'

1 Though as Elden (2010) identifies, the state is not the only means through which territory and territoriality can be understood. 
(Taylor 1994, p. 151). Sack (1983) sees territoriality as a spatial strategy to affect control over a space by connecting it to society by facilitating, enhancing and shaping economic, social and political relationships within a territory (Johnston 2001). Furthermore, Penrose (2002) argues that territoriality means that resources within a space are ring-fenced for a select group of people and that no other agent (either internal or external) than the state has legitimate authority within this domain (Krasner 1995). The idea that the state has a strategy to secure and enhance territoriality finds its rationale in the state as being equivalent to a rational individual in which it faces a choice of developing a proactive territorial strategy or losing its territorial rights, submitting to contested control or anarchy within its borders or becoming subject to this territoriality being violated by internal and/or external forces.

Vollaard (2009) offers a narrower notion of territorial strategy as a political strategy which establishes an institutional system that enables and constrains relations within a territory. This treatment stresses that territorial strategy establishes a logic in enabling and setting the parameters of political behaviour and all relationships within a territory without which territoriality would be subject to erosion. Thus territory is not a passive given but is upheld by political actors (Vollaard 2009). The higher the degree of control, the more the territory is subject to geographic fixity, exclusivity and centralised forces (Elden 2010). This latter point links geographic proximity to territorial strategy to decrease the costs of control and to enable the intensity of flows needed to assert power and gain legitimacy. According to Sack (1983), territoriality is historically derived and socially constructed and is an expression of power based on ongoing strategies to create and sustain the territory through the use of maintained borders to control access to resources.

Arrighi (1994) defines territorial strategy in more geo-strategic terms, arguing that it exists by seeking to maximise power by maximising the territory and population controlled. Thus wealth is a direct derivative of this process and is assumed to increase directly with overt territorial strategies and also through a process of territorial expansion. This links power to territorial enlargement but also, as expressed by Mann (1984), to the deepening of the container. This is in contrast with what Arrighi (1994) terms 'capitalist strategies' where power is linked to the control of resources within a small container and where the size and/or deepening of that container is justified by the requirements of the accumulation of wealth. In this case, territoriality is the means through which wealth is secured.

Many contemporary debates within international political economy and beyond have (albeit indirectly) limited the efficacy of territorial strategies 
as the exclusivity of state sovereignty within a given territory has been challenged. In short, the conventional perspective that territoriality and the state are synonymous is no longer robust (see, for example, Agnew 2005). Globalisation places an adaptive tension upon such strategies as all the forces that shape and influence territoriality can no longer be contained within the state's borders. Some authors (notably Agnew 1994) suggest that to assume it was always uncontested was a persistent error made by scholars within international political economy and related fields who not only failed to appreciate the complexity of the state system but lacked a stronger appreciation of the history of territorial configuration and reconfigurations. As Painter (2010) argues, the notion of territory can exist at multiple levels suggesting that there is no exclusivity with regard to the formation and implementation of territorial strategies (Riain 2000; Bouzarovski et al. 2015). However, as Dicken (1997) notes these processes are not simply about state adaptation through reactive strategies. States also look to be proactive in the global arena through operating beyond their borders to seek competitive advantage (see Palan et al. 1996).

Consequently, in the global era the state is, as Strange (1996) noted, but one player among many in the global economy and its territorial strategy must adapt to these circumstances. This is reinforced by questions over the extent to which the state requires exclusivity of action within a territory to fulfil its territorial objectives. As such, globalisation need not erode the legitimacy of state territorial strategy as its strategy seeks merely to assert power over those forces that challenge or erode its territorial objectives. Moreover, it has to be recognised (as advanced notably by Weiss 2005) that state territorial strategies can be enabled and/or enhanced by overlapping jurisdictions seeking to tap into extensive transnational networks to enable its strategy. This generates an overlap between the state, its territorial strategy and its broader geopolitical/geo-strategic actions/interests. This then leads territorial strategy to be defined less in terms of exclusivity and more in terms of the state operating as the predominant, legitimate agent amongst other (lesser) agents (both legitimate and illegitimate) seeking to meet a set of territorial objectives within a given space. In so doing, the state operates alongside benign or supporting external forces to control or enable all forces (both internal and external) that impact (either positive or negatively) upon a state's territoriality (see, for example, Mann 1997; Sassen 2000).

Based upon this definition, infrastructuring is treated as integral to territorial strategies with the process being driven by the need for the state to infrastructure in order to penetrate space to secure its power 
(Mann 1984). This penetration is both horizontal (over terrestrial and maritime spaces) and vertical (i.e. over subterranean and airspace). The state must have infrastructural power to penetrate and logistically implement its decisions across its territory. Historically this has been weak, but with the state-based system the state has encroached in infrastructure terms (Neuman 2006; Ghosn 2010). In understanding infrastructure as a tool of territoriality, there is a need to look beyond physical characteristics (for a review see Markard 2011) to examine the 'softer' aspects of their functioning, reflecting its existence as both a material and social tool (Howe et al. 2016). Star and Ruhleder (1996) highlighted such debates, suggesting that what actually constitutes infrastructure is a moving target with these authors stressing that it is characterised by:

- Being embedded into socio-economic systems to the point that it is (in effect) invisible at the point of usage and only becomes visible at the point at which it stops acting as infrastructure (i.e. it fails);

- Enabling relationships between users where users learn how to use infrastructure as part of their membership of a community of practice with this usage pattern being shaped by or adhering to standards, conventions and the actions/preferences of an installed user base.

Such issues highlight three important facets of infrastructure systems. First, that the importance of infrastructure is shaped by the rules and conventions of usage (Neuman 2006). Second, that building, establishing and maintaining relationships between users is core to the infrastructuring of territorial systems. Third, that 'to infrastructure' is as much about the act of and strategies embedded within the development, maintenance and adaptation of infrastructure that facilitate relations between users within a territory as the physical assets themselves. Such logic is embedded within the infrastructural mandate and its link to territorial strategies (see below). Importantly (especially for comprehending the efficacy of territorial strategies), infrastructural relations are only effective as a tool of territorial strategy at the point of usage; if a user is not using or has no intention of using infrastructure then it is not 'infrastructure' to that user (Edwards 2003). Thus, any single piece of infrastructure is not of universal and ubiquitous usefulness to every citizen and that, consequently, infrastructure is relative to the needs of the user.

The notion of embedded infrastructure (i.e. sunk into other activities and systems) has become increasingly challenged, with the state increasingly seeking to use such systems as an expression of its power, 
legitimacy and a means of discourse with its population (Mbembe 2001). Thus the state has no interest in 'hiding' infrastructure, leading to the existence of so-called suprastructures (i.e. those infrastructures that are not embedded within systems but made an explicit feature of them) (see Table 1.1). Larkin (2013) argues that (at best) invisibility is a partial truth as it is not ubiquitous and exists at one end of a range of perceptibility from the invisible to the big, grand edifices. The literature on anthropology highlights that this visibility is often seen in developing states where the infrastructure provision is linked to the process of modernity and the service is anything but taken for granted, to the extent that it can be given the name of the patron who financed the project. This highlights the exceptionalism of infrastructure which may diminish over time as it becomes 'taken for granted' (Winther 2008). Indeed, the exceptionalism of infrastructure and the detailed knowledge users develop of it, prohibits its ability to disappear into the background; at least over the short term (Carse 2012). Moreover, what is background for one user can be an object of daily concern for another (Barry 2001). Infrastructuring and its intimacy with modernity requires citizens to have a certain level of technical skills and know-how as a prerequisite of operating in modern systems (Mrazek 2002). This learning is not just about maintenance and installation; it also refers more self-evidently to the means and form of usage.

Territoriality within infrastructure systems reflects, according to Star and Bowker (2006), a legacy of a number of political economic, social and technological decisions. Such decisions will reflect on the relative priorities within the development of the territorial infrastructure system. These priorities reflect that within the development of the system there is the need to draw a line between core and non-core infrastructure. What is 'core' evolves over time reflecting the dynamics within the system as the expectations upon them and the technology upon which they are based change. Thus, whilst infrastructures exhibits continuity over the offering services that fulfil basic human needs, the way these are fulfilled has varied over time as has what is deemed essential to human needs (Jonsson 2005).

The systemic nature of infrastructure highlights that no piece of infrastructure exists as a standalone entity but that its value (in this case in territorial terms) is as part of a system (Hughes 1983). This systemness extends beyond intra-sector facilities to inter-sector links. In the latter case, at any single point in time and space, a user could simultaneously use multiple infrastructures (for example with the use of IT systems in the management of transport). The systemic nature of infrastructure means increasingly that one of the systems components cannot function 


\section{Table 1.1 Infrastructure vs suprastructure}

Infrastructure
Embeddedness: Infrastructure is sunk
into other structures, social
arrangements and technologies
Transparency: Infrastructure is
transparent to use and because it can be
reused for multiple tasks without the
need for re-invention or reassembly; it is
all but 'invisible' at the point of usage
Reach or scope: Expressed in spatial or
temporal terms, infrastructure can
extend beyond a single point in time
and/or space

Learned as part of membership:

Learning rules of infrastructure usage is part of social engagement and exclusion. Being a member of society necessitates understanding and adherence to these learned rules

Links with conventions of practice: Infrastructure interacts with local customs and practices to the extent that it is both influenced by and influences such conventions in the process of usage

Embodiment of standards: Infrastructure seeks to reconcile differing conventions and maintain transparency and enable interconnection with other infrastructures through the adoption of mutually agreed standards

Built on an installed base: Infrastructure builds upon other infrastructures and builds upon existing user bases and facilities. This can be both a source of strength and weakness for the system

Becomes visible upon breakdown: Infrastructure is invisible up until the point it fails as infrastructure (i.e. it fails)
Suprastructure

Ascendent: Infrastructure is explicit at point of usage; its use is a conscious act

Explicitness: It is visible via use of signs etc. to notify existence

Channelling: Gateways offer restricted spatial focus with flows

funnelled/channelled to key specified locations

Exclusion: Differentiation between groups non-national and nationals with differentiation in ease of usage

Adaptivity to practice: Infrastructure has to adapt to form and nature of flows but it also shapes flows by directing them

Connectivity: There is a need for points of de-and re-territorialisation of flows and to connect between systems based upon agreed protocols where possible

User differentiation: Infrastructures are built to differentiate between users based on nationality/rights of access to territory

Permanently visible: There is a virtue for infrastructures in being visible and acting as a statement of state competence and power

without (or at the very least has its 'value' to users enhanced by) its links to other infrastructures (Van der Vleuten 2004). This requires coordination between the component parts especially where there is simultaneity 
in usage (Rinaldi et al. 2001). This systemic facet has shaped debates with regard to system criticality. That is, those infrastructures whose failure would cascade throughout the system to the extent that it could challenge territoriality. The systemic characteristic also creates risk in that the territorial vulnerabilities are hidden. Thus, changing one part of the territorial system could alter (unintentionally) other parts of the territory's system. Thus, an infrastructure system is more than just the sum of its parts.

Despite changes in the ownership and control of infrastructure systems over the past three decades, the state remains the primary agent for infrastructuring. Even in those states (such as the US) where over two-thirds of economic infrastructure (i.e. energy, water, transport and information) are owned by non-state agents, the state still plays a pivotal role through soft infrastructural systems (see Chapter 6). Thus where the state does not directly own it will seek to steer the development of an infrastructure system to be compliant with its territorial objectives. This position runs counter to authors such as Strange (1996) who see the rise of the polycentric infrastructure system as a diminution of the power of the state without always considering its steering role to ensure compliance of diversity of ownership and control with its territoriality (see, for example, Moran 2002). Even where there is private infrastructure subsystems within infrastructure systems, these must connect (or run over) into public infrastructures to function, rendering them only virtually private due to their high dependency upon public systems (Graham and Marvin 2001).

Infrastructure is a rare point of consensus amongst economists and policy makers as to the validity of state intervention (Glykou and Pitelis 2011). The scale of infrastructure systems requires the management of space on a grand scale and only the state is capable of attaining this objective (Brenner 1999). The state can be used to overcome 'reverse salients' (Hughes 1983) - those sticking points that inhibit the development of infrastructure - such as low demand where the state uses various methods to stimulate network usage and development. The risk profile of infrastructure investments combined with issues over criticality and territoriality further legitimatises state intervention in infrastructure systems. These are also compounded by political reasons for public good investment (Gramlich 1994) and adapting to the challenges of globalisation. Harvey (1985) states that infrastructuring is core to the state and its territoriality, for as capitalism expands so the state needs to manage the implications of this process by seeking to fix resources to a state by enabling their mobility (Castells 2006). This stresses an inherent paradox: encourage mobility to promote fixity (Brenner 1998). This is also 
reflected within the neo-liberal logic of the competition state (see below) (Sassen 2000, 2013).

\section{INFRASTRUCTURING AND THE STATE: THE NATIONAL INFRASTRUCTURE SYSTEM (NIS)}

The NIS represents the totality of the networked infrastructures located within the demarcated borders of the state. ${ }^{2}$ Figure 1.1 identifies the core structural facets and operational inter-relationships that can be expected to be present within mature NISs. Such interconnections and interdependencies underscore the point that the NIS is more than just the sum of infrastructure located within the border of a state. As a territorial system, this framework reflects not just the aforementioned operational complexities of the system but also its spatial implications. Such spatial complexity opens up the possibility that the efficacy of the operation of the NIS (or a component or sub-system of it) in one part of a state's territory can have implications for the system's operation in other - if not all, if the component is deemed critical (see below) - parts of the state's territory. Spatial complexity also extends to inter-state infrastructural links and how the intensity of interactions between respective NIS can also influence the operation of another state's system (Turner 2018).

As stated above, within the contemporary international system, the state is the major territorialising agent with infrastructuring proving to be a major method of it establishing territorial control. In so doing, states built on preceding artefacts established by preceding territorialising agents each of which undertook their own infrastructuring to support their respective needs (Johnson and Turner 1997). Over time, the emergence of the polycentric system has seen NIS development shifting away from being a sole preserve of the state towards multiple agents being involved in its development and operation. Despite this, the state retains a primary role not just through its major financing capabilities but also through regulation, risk management, legitimatisation etc., via which it will seek to steer non-state activity towards its own objectives (see Chapter 6). Consequently, all infrastructure that is publically accessible has still to receive some degree of sanction from the state to support, enhance or at the very least not compromise its territorial strategy

2 This was similar to the definition offered by Professor Graham Winch of the Alliance Manchester Business School who defined it as the portfolio of assets which underpins the productive activity of the nation by providing essential infrastructure services to other sectors' (as noted in ISC 2017, p. 51). 


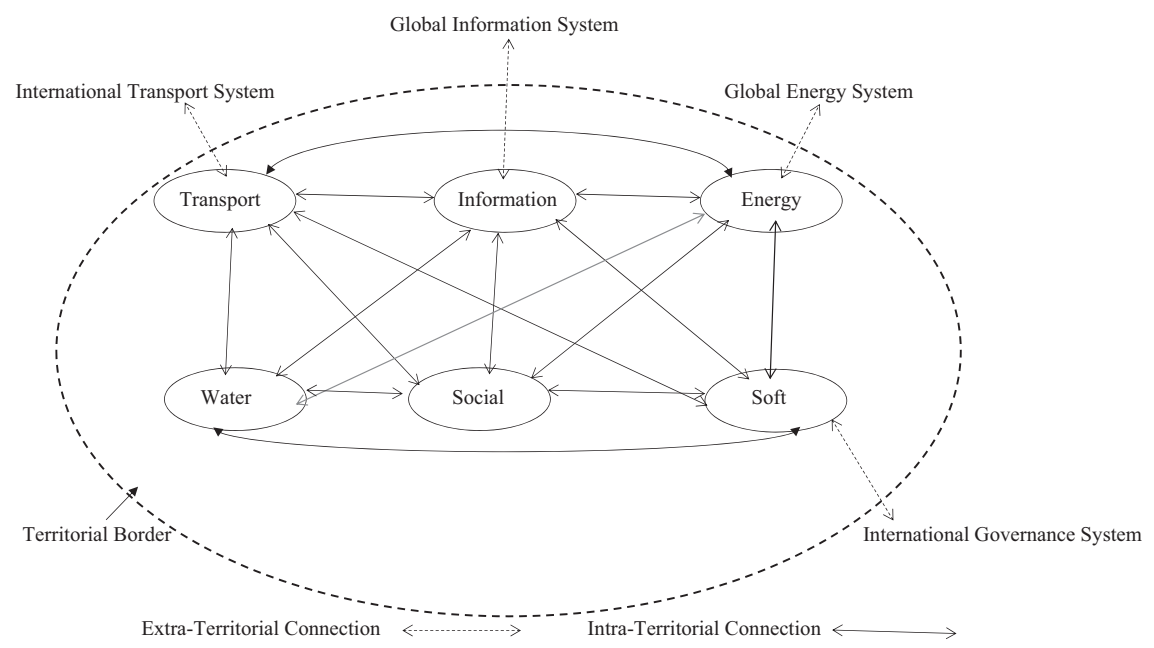

Figure 1.1 The national infrastructure system

(Schneider and Jäger 2003; Stilz 2011). Thus, the extent to which the move towards polycentric NIS is seen as an erosion of the power of the state can be overstated with the risk of failure in complex systems as well as embedded market failure and their legacy for state territoriality meaning that the state cannot abrogate infrastructuring from its territorial strategy (see below).

Infrastructure has been subject to change as the conventional notion of NISs being about the interlinkages and mutual support between largescale systems is being challenged by their structural fragmentation (Egyedi and Mehos 2012). These inverse infrastructures do not seek to compromise the system virtues of the NIS but to offer greater user responsiveness. The immediate legacy is to increase the complexity of the system as the NIS is formed by a mix of centralised top-down and disaggregated 'bottom-up' strategies (Graham and Marvin 2001). These inverse infrastructures reflect how liberalisation is altering the method of developing public infrastructure within mature polycentric infrastructure systems. In fact, such fragmentation reflects a full circle development of infrastructure as it moves back towards more localised provision which was the norm for much of the 19th century (Egyedi and Mehos 2012). These local systems are still part of the NIS with local bodies still largely dependent upon state sanction and/or finance (see for example Turner 2018). These delegated processes allow integration and growth/ development of the state without depleting control. 


\section{Table 1.2 A simple typology of the components of the NIS}

Economic Infrastructures Enabling Infrastructures

- Transport: these are the road, rail, maritime and aviation facilities that support the mobility of goods, services and people within and between states (see Chapter 2)

- Information: these are physical structures that support the transmission, utilisation and processing of data (see Chapter 3)

- Energy: these are the facilities to enable the extraction, generation, storage and transmission of both renewable and non-renewable energy resources (see Chapter 4)

- Water: these are the structures that support and enable the supply, treatment, storage and management of water resources (see Chapter 5)
- Soft infrastructure: this a more ambiguous term but here it is defined as those institutional systems that facilitate the development and operation of hard infrastructure in a form that is aligned with the needs of the infrastructural mandate including standards, human capital, finance and accessibility (see Chapter 6)

- Social infrastructure: these are less explored but are core to the NIS. These are the physical structures that enable the supply of core public/social services such as healthcare and education (see Chapter 7)

For simplicity, the NIS (as conceived within Table 1.2) ${ }^{3}$ is sub-divided into differing types of infrastructure:

- economic infrastructures: these are those infrastructures whose formative function is to support commercial activity and economic development within a territory but in so doing also enable territorial political and social development as well as its integration/cohesion.

- enabling infrastructures: these are those tangible and intangible social and institutional structures which (both directly and indirectly) enable the effective operation of economic infrastructure to realise the state's territorial strategy.

3 Jochimsen (1966) offered a more disaggregated approach identifying three components to infrastructure based on materials, institutional and personal infrastructure. The advantages of such an approach are that it enables a clear differentiation between the effects and determinants of infrastructure (Buhr 2003). Material infrastructures are conventional economic and social facilities that enable economic and social interaction. The institutional infrastructure finds its proxy in the issue of soft infrastructure examined in Chapter 6 whereas personal infrastructure finds its proxy in the impact of social infrastructure examined in Chapter 7 (see, for example, Buhr 2009). 
The role of territorial strategy with regard to infrastructuring depends on the maturity of respective NISs. Table 1.3 reflects what can be expected to be the major facets of a mature NIS assuming the system is maintained and adapting to contextual tensions. Whilst the infrastructural mandate is treated as ubiquitous across all states, the relative priority of its facets will differ according to a range of criteria such as level of development, maturity of NIS, criticality issues etc. The mandate reflects Mann's (1984) core synthesis of the main functions of the state with the components of the mandate being mutually supporting and overlapping in their design and operation. As identified in Johnson and Turner (2017) and Turner (2018) the components of the infrastructural mandate are control, security, integration and growth/development. These established criteria have been supported by a fifth identifiable component: sustainability. The interface between each of these components and state territorial strategy are explored more fully below.

\section{Table 1.3 The core facets of a national infrastructure system}

\begin{tabular}{ll}
\hline NIS Facet & Description \\
\hline Universality & $\begin{array}{l}\text { The NIS should offer a basic, minimal level of services/access to all } \\
\text { parts and all socio-economic groups within the territory. This does } \\
\text { not imply uniformity of service - as some groups may require } \\
\text { differing terms of access - just that right to access basic services is } \\
\text { often linked to basic human rights. }\end{array}$ \\
Connectivity & $\begin{array}{l}\text { No single infrastructure is isolated from any other part of the NIS. } \\
\text { This reflects both functional and spatial interdependencies between } \\
\text { these components with these links being driven by one or more of } \\
\text { the following interdependencies (Rinaldi et al. 2001): physical, cyber } \\
\text { and/or geographical. } \\
\text { The NIS has to have the ability to connect into global networks to allow } \\
\text { for the de- and re-territorialisation of flows. Whilst states will seek to } \\
\text { filter such flows to protect their territoriality, there is also a recognition } \\
\text { that they need to facilitate these flows to enhance state territoriality. } \\
\text { There are sub-sections of the NIS whose failure would directly under- } \\
\text { mine the territorial capability of the state. Their failure would - over a } \\
\text { short period of time - undermine the infrastructure mandate and erode } \\
\text { the welfare of the territory citizens. These critical components are those } \\
\text { parts of the NIS whose failure would resonate widely throughout the } \\
\text { system and directly limits flows within and beyond it. } \\
\text { The quality of the NIS is core to its reliability and certainty of } \\
\text { provision. There is an expectation by users over certainty of usage } \\
\text { and of its ready-handness to ensure the NIS's resilience. The quality } \\
\text { of the system is core to the NIS's reliability and its ability to absorb } \\
\text { and withstand disturbances and crises and involves the system } \\
\text { exhibiting functional flexibility and an ability to recover when } \\
\text { suffering a disturbance. }\end{array}$ \\
Quality &
\end{tabular}




\begin{tabular}{ll}
\hline NIS Facet & Description \\
\hline Quantity & $\begin{array}{l}\text { The NIS should have sufficient capacity to cope with actual and } \\
\text { anticipated demands placed upon it. Moreover, it is anticipated that } \\
\text { the system exhibits sufficient redundancy (i.e. spare capacity and } \\
\text { back-up systems) to enable the system to maintain operation where } \\
\text { the system was subject to an unexpected disturbance. }\end{array}$ \\
\hline
\end{tabular}

\section{Control}

Control is intimate to territoriality, and infrastructure, as Mann (1984) argues, is central to the definition of what constitutes a territory (Giddens 1985; Brenner 1999; Elden 2010, 2013). An extensively developed infrastructure system allows the state to penetrate civil society through its ability to generate and move resources (both tangible and intangible) around a territory. Through such penetration the state is able to exercise ideological, economic, military and political control (Mann 1997). Control within a relational infrastructure system becomes salient when users become dependent upon the existence of the services offered for their existence. This reliance can be through a mix of formal (i.e. access methods etc.) and informal (such as the shaping of social, cultural and personal norms) methods. Thus control is not just through the direct exercise of power by the state, it is also through strategies shaping individual interactions with infrastructure to make agents behave in certain ways within the context of its mandate (Rose and Miller, 1992; O'Malley, 1996). In this context, the state's infrastructure system operates as a channel for social regulation through which the state acquires the capacity to assert power over a territory. For these reasons, the state often feels compelled to control infrastructure either via direct ownership or through regulatory structures (Braithwaite and Drahos 2000; Moran 2002). This has found its most evident contemporary expression in critical infrastructure strategies (see, for example, Brown 2006).

Rodgers and O'Neill (2012) argue that infrastructure can be an embodiment of violence and function as its instrumental medium (see also Graham 2004). Violence flows through these structures in that they can be used to embed poverty and erode justice. This infrastructural violence is not simply about infrastructure existing as a channel for control but also that intentional infrastructural under-development can also be utilised as a strategy to subjugate (see Farmer 2004). Thus at the confluence of territorial control and integration, control can also be asserted by the intentional absence, under-development, degradation and/or denial of access to infrastructure. This can work to quarantine 
internal threats by isolating groups that work to challenge state power. However, it can also fuel internal security threats if such infrastructural violence fuels a sense of resentment.

As control has a core focus upon the maintenance of internal security, its salience has been underlined by the literature on state failure. Thus expressed in territorial terms, the logic of a failed state implies failed territorial strategy where the state through its actions is unable to control its territory notably in terms of its monopoly over violence (Jackson 1993; Krasner 2004; Lemay-Hébert 2013). The state failure literature stresses the importance of under-development, deterioration or failure of infrastructure in this process (Carment 2003). States begin to lose legitimacy when they are no longer able/willing to provide basic functions (notably security) for their citizens (Zartman 1995; Rotberg 2002). This can be via intent, outright neglect or simply where the state cannot control a territory (or part of) to maintain the system. Importantly, the failure of the infrastructure system is more symptomatic of political failure than a cause of state collapse in its own right (Taylor 2013). Many internal rival powers will seek to fragment the NIS as a platform for challenging the exclusivity of the state. In some cases, these bodies may have an incentive to allow infrastructures to deteriorate or not seek to upgrade systems as they may cement state power (Di John 2008). Rabosa et al. (2007) argue that a core facet in enabling terrorism is the existence of an extensively developed infrastructure system. This allows for organisation of acts but also opens channels for disruption. This suggests the existence of the potential for cannibalistic pressures within the NIS.

\section{Security}

The notion of the border is central to the concept of territoriality where the state has the recognised right to monitor and control flows in and out of its demarcated space. As the state is the guarantor of security, one of its main functions is guarding the NIS against external disruption and in utilising infrastructural gateways (see Chapter 6) to exclude illegal/illicit flows (Gilpin 2011). Modern states face the challenge of balancing the desirability of globalising their NIS with the need to secure their operation (see, for example, Held et al. 1999; Williams 2003; Scholte 2005). This reflects that increased interactions and interconnections within and between NIS renders these systems vulnerable to a multitude of threats and dangers born of how spatial complexity and global change has created uncertainty over the stability and sustenance of relational infrastructure systems (Rotberg 2002; Moteff 2012). As mentioned below, states have to adapt NISs to assorted environmental forces that 
can disrupt infrastructural relations and thereby undermine the NIS's functioning and compromise the state's infrastructural mandate (Rinaldi et al. 2001; OECD 2008).

Security has often found resonance within debates on criticality within NIS. These critical infrastructures are those parts of the system that are central to the exercise of territoriality and whose failure would directly challenge state capability in implementing territorial strategy. In these cases, the state - within the context of a polycentric system - will seek to regulate control, ownership and operation of such infrastructures in the name of security. Those under non-state ownership that impede the set frameworks of operation run the risk of expropriation. These concerns have especial resonance in border/gateway infrastructures where externally-sourced flows are filtered to remove illicit flows. As Larkin (2013) mentioned, these 'supra-structures' are intentionally visible as a means of conveying state power and its security apparatus. This narrative stresses that in a global system of flows states will still retain the right to vet the de- and re-territorialisation of flows. This theme is evident within Graham (2010) and the notion of infrastructural warfare, where states need to ensure NISs are secure from harmful external flows which are directly targeted to result in lowering citizens' welfare as a means of undermining state territoriality.

\section{Integration}

There is, as identified by Markard (2011), an intimacy between the welfare of citizens and the state of the infrastructure system. This reflects that there is an expectation that the services offered by the NIS are reliable, affordable and of high quality and that these characteristics are universal across a territory. Such universality across a territory (as well as socio-economic strata) is, according to Hartshorne (1950), core to the state's basic tasks in establishing control and securing the loyalty of the territory's population. This reflects a main (and continuing) problem of countering centrifugal tendencies within economic development within the territory. Hartshorne identified ethnic, linguistic, religious and economic diversity as a source of strain on 'the state idea'; these can be mobilised and reconfigured, as a major source of integration (Hartshorne 1950). Thus, whilst there is a clear narrative on the role of infrastructure in promoting more even economic development (see, for example, Nijkamp 1986; Brocker and Rietveld 2009), it is also important to stress that the integrative elements inherent within an NIS extend beyond such narrow economic developmental approaches. 
Infrastructuring as a means of territorial integration is focused upon enabling time-space and cost-space compression (Giddens 2013). These processes assume that territoriality involves improving links to promote (as mentioned) economic development, social cohesion and political inclusiveness (Munnel 1992; Rietveld 1995; Edwards 2003). This does not simply mean ensuring that the infrastructure system reaches physically remote or peripheral regions but also those areas (both urban and rural) where there is social, political and economic exclusion (see also Martin and Rogers 1995). This identifies that territorial integration is a mix of vertical (for social groups) and horizontal (for territorial groups) processes. In this context, the NIS lies at the confluence of policies from social to regional policy that seek to enable access to infrastructure as a means of promoting territorial cohesion. These themes are in part a reflection of Lefebvre's notion of abstract space which perceives that the role of the state is to create territorial homogeneity through the enabling of social, political and economic relations (see Lefebvre 1978; Brenner 1999).

This notion of infrastructure as a tool of territorial integration has found a high-profile expression within the 'modern infrastructural ideal' (Graham and Marvin 2001). This stresses universality and uniformity of services (though this often applies to the most basic level of service). The shift towards polycentric systems of provision has stimulated more market-led NISs which has prioritised growth over inclusion (Estache 2007). One of the legacies of this process, according to Graham and Marvin (2001), has been a splintering of the NIS. This occurs as infrastructure provision varies according to user requirements rather than being guided by principles of universality. The consequence of this splintering process is to create the risk of power asymmetries across a territory (Massey 2005) which risks inhibiting territoriality (Mann 1997; Offner 1999). Thus the infrastructural ideal is a core force for social solidarity and its erosion has the potential to undermine the objective of the state's territorial strategy. These have found expression within the need to create a universal basic infrastructure (UBI). A UBI seeks universality of high-quality economic infrastructure so as to improve integration alongside that which boosts productivity. This sees infrastructure with a strong social function to promote not just growth but growth that is more even across socio-economic groupings (ISC 2017).

The adaptive tensions upon the NIS created by globality (see below) have reshaped the integrative aspect of the infrastructure mandate, as there is an increased emphasis within policy initiatives to promote integration into global markets, logistical systems and production networks (see, for example, Coe et al. 2004). At the national level, this is 
driven by the needs of the competition state (see below) and enabling international interaction through the development of an export-enabling infrastructure not just at the point of entry and exit of flows but also within hinterland systems. This integration extends beyond the national level into sub-national level strategies. This reflects a need for regional strategies to reflect globalisation. This globalising of regional integration has led to a focus on integrating regions into global production networks (Coe et al. 2004). These links need not be transnational and indeed may be based on establishing national clusters.

\section{Development/Growth}

Much of the contemporary analysis of NISs has been shaped by the logic of neo-liberalism. This is evident in analysis of infrastructure systems undertaken by organisations such as the World Bank and the World Economic Forum (WEF). These reflect the logic of endogenous growth theory (Romer 1994) and that a core focus of territorial strategy has to be improving citizen welfare through economic growth. The link between growth and the NIS is through the role that it plays in organising and allocating resources within a state (see for example Canning and Pedroni 2004). Narratives on the development of the NIS as a growth catalyst have strong internal and external dimensions. Internally the logic is enhancing the domestic allocation of resources allowing growth to be diverted away from congested cores to less developed peripheries (Martin and Rogers 1995). This logic is to allow growth to be balanced across a territory to ensure the territory does not face long-term structural imbalances (Munnell 1992; Storper 1997). Such priorities are aligned with the promotion of territorial cohesion and integration mentioned above and promoting inclusive growth/development. The state of the NIS reflects the basic precondition of a modern economy enabling it to adapt to challenges and to allow for its efficient organisation through efficient circulation. This, according to Agénor (2010), extends beyond economic infrastructure towards social infrastructure highlighting how the provision of education and health care increases human and social capital and therefore acts as a platform for development through enhancements in productivity (see Chapter 7).

Externally, the nexus of the NIS and growth has been encapsulated within narratives surrounding the competition state and how the NIS is a platform for the global positioning of the state (Romp and de Haan 2007). In this context, investment in the NIS is to support the globalisation of the state by enabling markets and lowering the transactions costs associated with global interaction (Glykou and Pitelis 2011). This 
positions the NIS as an integral part of the state's export system operating as the means through which commodities and fully- and part-finished products are moved to the state's gateways. These gateways are shaped by the need to interact - as an economic need - with the global system where the NIS is seen as a catalyst of value creating relationships. By implication, the state has an incentive to develop and push users towards the parts of the NIS that have a positive impact on performance (Fougner 2006). The pressure from the competition state should in theory lead states to develop those systems that reflect and stimulate traffic flows both within the states and between states.

Looking towards growth for development, it is evident that infrastructure is seen as central to poverty reduction through the promotion of industrialisation (Estache 2010). The development of infrastructure is seen to offer two benefits. The first is through raising productivity and lowering production costs. The second is through having a disproportionate effect on poverty reduction by raising incomes, increasing returns on assets, aiding the developing of human capital, assisting the realisation of scale and enabling the spread of knowledge (Henckel and McKibbin 2017). Sawada (2015) notes that for less-developed states the provision of infrastructure is core to longer-term improvements in welfare to attract international investment. This involves creating mature NISs rather than upgrading pre-existing systems. The development of mature NISs is seen as vital when not merely engaging in industrialisation to militate otherwise remoteness from major markets but also to move beyond infrastructure for natural resource extraction. As these developing regions are caught in a cycle of infrastructure underdevelopment, it is often multilateral development banks and possibly overseas governments or multinational businesses that seek to stimulate their development, though often it is the former two that dominate due to the need to correct market failures that limit NIS development (Hansen et al. 2012).

\section{Sustainability}

The notion of territorial sustainability has become an increasingly prominent theme within infrastructuring. Territorial sustainability reflects two narratives. First, that sustainability is increasingly core to the state's function and to the welfare of citizens and that the ability to sustain territoriality is driven by the need to secure these aspects of the quality of life (Kates et al. 2005). Second, is the idea that territoriality can only be sustained where it operates as a self-sustaining system where there is no net depletion of resources as a consequence of the strategy (see Coenen et al. 2012). Thus, territorial strategy should not come at the cost of 
eroding the natural environment where ultimately the resources available will not be able to support the actual and anticipated population. Indeed, sustainability should be at the core of territorial strategy (NCE 2016). Such debates are most frequently encapsulated within debates upon sustainable development (see Redclift 2005). As Giovannoni and Fabietti (2013) note, over time these themes have diversified to stress themes of socio-economic inclusion alongside environmental issues as identified within the UN's Millennium Development Goals (see Drexhage and Murphy 2010).

These themes of sustainability have been extended to infrastructure. Sustainability often fits between multiple themes within the infrastructure mandate. Thus, the core theme is often achieving one objective (such as growth) without compromising the quality and quantity of natural resources which are seen as central to social wellbeing (see, for example, OECD 2011). This reflects a position that the development of an NIS should be 'efficient' in its use of natural resources (World Bank 2012). Conventionally infrastructure would be seen as going against the process of sustainability both in terms of its construction and usage, each of which promotes environmental degradation (Sarté 2010). Indeed, usage of infrastructure is estimated to account for 60 per cent of greenhouse gas emissions (NCE 2016). Aligning infrastructure systems with sustainability means designing, creating, operating and upgrading systems in a fashion so as - at the very least - not to lower those processes (economic, social and ecological) necessary to the operation of human and natural systems. These themes have also been evident within an infrastructure policy that has been increasingly shaped by narratives surrounding the developing of sustainable infrastructure (Dasgupta and Tam, 2005). This could imply the localisation of systems to ensure responsiveness but also that sustainability ensures the resource is sufficient over its lifetime to prevent decline, that it is responsive to evolving user needs and is reflective of its social-economic context (see, for example, Bhattacharya et al. 2015).

There is an expectation that infrastructure systems should be structured and operate in a manner that does not harm the social, economic and ecological processes necessary to facilitate and sustain human equity, diversity and the functionality of natural systems. This can often link infrastructure development with the embrace of new technologies that promote rational use of both infrastructure and the resources involved in its utilisation. This seeks over time to decouple (at least in relative terms) infrastructure development and usage from environmental degradation (see Hickel and Callis 2019). Such narratives are frequently focused on 
energy systems and on the switch to less use of carbon in the production of energy, notably through the utilisation of renewable resources. There is also a focus on transport with the use of electric vehicles to steer away from the use of oil in this sector and the need for an infrastructure to support this objective. These are compounded by other trends such as the utilisation of 'green' infrastructure in water, the replacement of physical mobility via transport through 'virtual transmission' and the use of renewable materials in system design and construction. In practice, decoupling in absolute terms is impossible, meaning that sustainability reflects more a desire to minimise impact of NIS development and usage.

\section{THE SHIFTING CONTEXT OF NIS}

Infrastructuring as a device of territoriality is under a process of constant change driven by shifts within the environmental context in which the NIS operates. This places pressure upon the NIS to adapt to shifting contexts to ensure that it (or at least a component of it) does not lose its fitness for purpose. These themes have been evident within the infrastructure as complex adaptive systems' literature (see, for example, Rinaldi et al. 2001) which stresses that the NIS is under evolutionary pressures from its environment and that its adaptation occurs through learning processes. The context of any piece of infrastructure reflects the broad operating environment (including other infrastructures) that affects its ability to act as infrastructure. These contextual drivers are exogenous to the system but apply adaptive tensions upon it. The major contextual drivers as identified by the literature are noted below (Rinaldi et al. 2001; Hall et al. 2012).

- Changes to the national economy. This will impact upon the ability of a citizen to buy infrastructure services and will thus affect demand for such services. In turn, the state of demand will affect the ability of the system to attract the necessary finance from state and non-state resources to invest in the necessary changes. Higher economic growth can be expected to positively impact on the traffic flowing over systems thus potentially placing pressure on systems and creating the risk of congestion in NISs where they do not have sufficient capacity and/or redundancy at a particular time and/or place.

- Demographic changes. Very broadly, it can be assumed that an expanding population places pressure upon the NIS as demand for 
infrastructure services can be expected to increase. Moreover, falling populations are also linked to a decline in the quality of infrastructure. Such links are not always straightforward as the relationship also depends on the nature of the state's demography. That is, the age structure shifts in its location, education levels etc. For example, an ageing population might mean population decline over the longer term but may require investment in infrastructure to support labour-saving technologies etc. In short, demographic change may simply require adaptation through new types of infrastructure.

- Natural environmental changes. As suggested above, changes in the natural environment (and of policies to limit the impact of these changes) impact on NISs on a number of levels. First, is that infrastructure becomes subject to unexpected oscillations in weather and, over the longer term, climate change, which can cause an increased risk of system failures (e.g. flooding of transport systems etc.). Second, it may place pressure upon those infrastructures that transport naturally occurring resources (such as water) requiring investment in new systems as weather becomes more unpredictable or as climatic conditions shift (Furniss et al. 2018). Third, the process may stimulate a shift away from one type of infrastructure towards others, for example, a move away from carbon-based systems towards renewables.

- Globality. As has been mentioned above, globality has had a direct impact on state territoriality as it would be expected that NISs have to adapt to reflect this trend within territorial strategies. This adaptive tension can be expressed through multiple processes. First, through capacity in transport gateways where flows are de- and re-territorialised. Second, that the quality of the NIS is sufficient to attract globally 'footloose' capital. Third, that the NIS can interwork with other national systems possibly within a global framework of rules (Johnson and Turner 2017).

- Public policy/state strategy. These will impact upon the development of the NIS through a multitude of channels that can operate in a positive and negative fashion. The salience of such measures has been shaped by the move towards polycentrism within the NIS and where the state can via direct (for example security, energy and economic strategies) and indirect (for example health and safety rules) actions influence the development of the system. These and other actions can shape the broad risk profile of the infrastructure 
and shaping the nature of the obligations upon NIS owners and developers. The state can be proactive through $\mathrm{R} \& \mathrm{D}$, shaping universal services agreements and other sector-specific issues such as de-regulation.

\section{$* * *$}

Markard (2011) identified that the ability of NISs to adapt to those pressures placed upon them can be sourced from a number of major factors. One is that the very systemic nature of NISs can be a barrier, as the increased risk and costs of innovation lead to system inertia. Second, high capital intensity means that owners have an incentive to monetise an asset rather than adapt to change that could render it redundant or limit revenue flows from it. Third, the simple cost of investment to adapt to change could be prohibitive. Fourth, environmental impacts of adaptation could be prohibitive to the extent that it defers change. Fifth, firm strategies can also impact on change as these firms tend to have low responsiveness to external pressures due to issues of scale and sunk costs. Finally, regulation can also play a role through shaping behaviour in aspects such as pricing and investment. These retardants to change within a complex NIS can create a number of problems within it that can impinge upon system operation, and prevent it from acting as a tool of territoriality. Howe et al. (2016) indicate that many of the problems created by the absence of adaptation to adaptive drivers are more relevant for developed states where NISs are more mature and where failure tends to be rare. This contrasts with developing states where failure is more normal and where there is lower capability to adapt to these pressures.

Howe et al. (2016) argue that as much as infrastructures remain vulnerable to future trends, they can also be expected to degenerate through natural processes. This reflects a need for systems to be constantly refurbished and updated. Where the NIS (or any component of it) is taken for granted the more difficult it is for the system to adapt and predict infrastructural failure. Such pressures underscore that adaptation should not be taken for granted as within any NIS there are many barriers to the process. These main barriers to adaptation within an NIS are identified in Table 1.4. Many of these major systemic barriers to NIS adaptation are a direct legacy of the issues raised above. They stress a need for constant investment as the NIS must adapt to long-term processes but also recognise that its systemic and complex nature can render it vulnerable to events that can also erode its territorial fitness. 


\section{Table 1.4 Barriers to adaptation within infrastructure systems}

\begin{tabular}{|c|c|}
\hline Barrier & Nature of Impediment to Adaptation \\
\hline bsolescence & $\begin{array}{l}\text { This occurs where infrastructure is no longer relevant to the needs } \\
\text { of the state as the infrastructure becomes divorced from its shifting } \\
\text { context (see above) }\end{array}$ \\
\hline Senescence & $\begin{array}{l}\text { This is the erosion and degradation of infrastructure generated by } \\
\text { the ageing process and the system being too slow to change to its } \\
\text { shifting contextual drivers, leading to increased risk of failure with } \\
\text { increasingly disruptive effects }\end{array}$ \\
\hline omplexity & $\begin{array}{l}\text { This occurs where infrastructure and its interlinkages grow so } \\
\text { complex that it can fail in a multitude of ways which can impact } \\
\text { upon the shifting context of the system }\end{array}$ \\
\hline $\begin{array}{l}\text { ystem } \\
\text { ilures }\end{array}$ & $\begin{array}{l}\text { Related to the above, these failures result from interdependencies } \\
\text { which can be cascading (i.e. disruption in one case, failure of a } \\
\text { component in another), escalating (an existing disruption } \\
\text { exacerbates the disruption of another infrastructure) or common } \\
\text { cause (where two or more infrastructures are simultaneously } \\
\text { disrupted) failures }\end{array}$ \\
\hline $\begin{array}{l}\text { ailing soft } \\
\text { frastructure }\end{array}$ & $\begin{array}{l}\text { This is reflective of the inability of the supporting institutional } \\
\text { systems to stimulate NIS adaptation to its shifting contextual } \\
\text { drivers }\end{array}$ \\
\hline $\begin{array}{l}\text { Loss of } \\
\text { infrastructural } \\
\text { heterogeneity }\end{array}$ & $\begin{array}{l}\text { The close interconnection between different infrastructures opens } \\
\text { up the prospect that they become so tight that they involve } \\
\text { simultaneous consumption both in time and space. This means } \\
\text { adaption requires more large-scale adaption of multiple systems }\end{array}$ \\
\hline $\begin{array}{l}\text { Divergent } \\
\text { polycentrism }\end{array}$ & $\begin{array}{l}\text { This results from a process where polycentrism (and the desire of } \\
\text { providers to sustain fragmentation) leads to divergent systems } \\
\text { based on differing soft infrastructural components that has the } \\
\text { effect of limiting interoperation within an NIS }\end{array}$ \\
\hline $\begin{array}{l}\text { Modular } \\
\text { complexity } \\
\text { failure }\end{array}$ & $\begin{array}{l}\text { Any given piece of infrastructure is increasingly modular with the } \\
\text { result that any single module could fail to adapt due to a divorce } \\
\text { from adaptive tension or due to disputes as to the nature of } \\
\text { adaptation }\end{array}$ \\
\hline $\begin{array}{l}\text { 'Boiled frog } \\
\text { effects' }\end{array}$ & $\begin{array}{l}\text { This is where adaptive tensions are so small/indiscernible that the } \\
\text { infrastructure fails to adapt, resulting in loss of 'fit for } \\
\text { purposeness' }\end{array}$ \\
\hline
\end{tabular}

Source: McKelvey (2002) and Johnson and Turner (2017).

\section{CONCLUSIONS}

Infrastructuring is core to state territorial strategies. These strategies need a developed infrastructure system to enable them to control, secure, 
integrate, grow and render sustainable the territorial space the state occupies. The centrality of territoriality to the state has traditionally meant that it has taken a pivotal role in the development of NISs. Such systems are formed against a dynamic context with the result that there are constant pressures upon states to adapt these systems to ensure that they sustain fitness to the needs of the territorial state. However, the adaption of NISs faces a number of barriers as these systems have grown ever more complex.

\section{REFERENCES}

Agénor, P.R. (2010). A theory of infrastructure-led development. Journal of Economic Dynamics and Control, 34(5), pp. 932-950.

Agnew, J. (1994). The territorial trap: The geographical assumptions of international relations theory. Review of International Political Economy, 1(1), pp. 53-80.

Agnew, J. (2005). Sovereignty regimes: Territoriality and state authority in contemporary world politics. Annals of the Association of American Geographers, 95(2), pp. 437-461.

Arrighi, G. (1994). The Long Twentieth Century: Money, Power, and the Origins of Our Times. London: Verso.

Barry, A. (2001). Political Machines: Governing a Technological Society. London: Continuum.

Bhattacharya, A., Oppenheim, J. and Stern, N. (2015). Driving sustainable development through better infrastructure: Key elements of a transformation program. Brookings Global Working Paper Series. Washington.

Bourdieu, P. and Farage, S. (1994). Rethinking the state: Genesis and structure of the bureaucratic field. Sociological Theory, 12(1), pp. 1-18.

Bouzarovski, S., Bradshaw, M. and Wochnik, A. (2015). Making territory through infrastructure: The governance of natural gas transit in Europe. Geoforum, 64, pp. 217-228.

Braithwaite, J. and Drahos, P. (2000). Global Business Regulation. Cambridge: Cambridge University Press.

Brenner, N. (1998). Between fixity and motion: Accumulation, territorial organization and the historical geography of spatial scales. Environment and Planning D: Society and Space, 16(4), pp. 459-481.

Brenner, N. (1999). Beyond state-centrism? Space, territoriality, and geographical scale in globalization studies. Theory and Society, 28(1), pp. 39-78.

Brocker, J. and Rietveld, P. (2009). Infrastructure and regional development. In R. Capello and P. Nijkamp (eds), Handbook of Regional Growth and Development Theories, Cheltenham, UK and Northampton, MA, USA: Edward Elgar Publishing, pp. 152-181.

Brown, K.A. (2006). Critical Path: A Brief History of Critical Infrastructure Protection in the United States. Wooster, Ohio, US: Spectrum Publishing Group. 
Buhr, W. (2003). What is infrastructure? University of Siegen Discussion Paper No. 107-03.

Buhr, W. (2009). Infrastructure of the Market Economy. Discussion Papers in Economics No. 132-09.

Canning, D. and Pedroni, P. (2004). The effect of infrastructure on long run economic growth. Harvard University, pp. 1-30. https://web.williams.edu/ Economics/wp/pedroniinfrastructure.pdf. Date accessed 08/02/2018.

Carment, D. (2003). Assessing state failure: Implications for theory and policy. Third World Quarterly, 24(3), pp. 407-427.

Carse A. (2012). Nature as infrastructure: Making and managing the Panama Canal watershed. Social Studies of Science, 42(4), pp. 539-563.

Castells, M. (2006). The Space of Flows. London: Wiley-Blackwell.

Coe, N.M., Hess, M., Yeung, H.W.C., Dicken, P. and Henderson, J. (2004). Globalizing regional development: A global production networks perspective. Transactions of the Institute of British Geographers, 29(4), pp. 468-484.

Coenen, L., Benneworth, P. and Truffer, B. (2012). Toward a spatial perspective on sustainability transitions. Research Policy, 41(6), pp. 968-979.

Dasgupta, S. and Tam, E.K. (2005). Indicators and framework for assessing sustainable infrastructure. Canadian Journal of Civil Engineering, 32(1), pp. $30-44$.

Dicken, P. (1997). Transnational corporations and nation-states. International Social Science Journal, 49(151), pp. 77-89.

Di John, J. (2010). The concept, causes and consequences of failed states: A critical review of the literature and agenda for research with specific reference to Sub-Saharan Africa. The European Journal of Development Research, 22(1), pp. 10-30.

Drexhage, J. and Murphy, D. (2010). Sustainable Development: From Brundtland to Rio 2012, Background paper for the high level panel on global sustainability, New York: United Nations.

Edwards, P.N. (2003). Infrastructure and modernity: Force, time, and social organization in the history of sociotechnical systems. Modernity and Technology, available at http://pne.people.si.umich.edu/PDF/twente.pdf. Date accessed 02/01/2018.

Egyedi, T.M. and Mehos, D.C. (eds) (2012). Inverse Infrastructures: Disrupting Networks from Below. Cheltenham, UK and Northampton, MA, USA: Edward Elgar Publishing.

Elden, S. (2010). Thinking territory politically, Political Geography, 29(4), pp. 238-241.

Elden, S. (2013). Secure the volume: Vertical geopolitics and the depth of power. Political Geography, 34, pp. 35-51.

Estache, A. (2007). Current Debates on Infrastructure Policy (Vol. 4410). World Bank Publications.

Estache, A. (2010). A Survey of Impact Evaluation of Infrastructure Projects, Programs and Policies. ECARES Working Paper. No. 2010-005. Brussels: European Center for Advanced Research in Economics and Statistics.

Farmer, P. (2004). An anthropology of structural violence. Current Anthropology, 45(3), pp. 305-325. 
Finger, M., Groenewegen, J. and Künneke, R. (2005). The quest for coherence between institutions and technologies in infrastructures. Competition and Regulation in Network Industries, 6(4), pp. 227-259.

Fougner, T. (2006). The state, international competitiveness and neoliberal globalisation: Is there a future beyond 'the competition state'? Review of International Studies, 32(1), pp. 165-185.

Furniss, M.J., Little, N.J. and Peterson, D.L. (2018). Effects of climate change on infrastructure. Chapter 11 in Jessica E. Halofsky, David L. Peterson, Joanne J. Ho, Natalie J. Little and Linda A. Joyce (eds), Climate Change Vulnerability and Adaptation in the Intermountain Region (Part 2). Gen. Tech. Rep. RMRS-GTR-375. Fort Collins, CO: US Department of Agriculture, Forest Service, Rocky Mountain Research Station, pp. 339-362.

Ghosn, R. (2010). Flow and its others: Fixity, fragmentation, and friction, Proceedings of the Association of Collegiate Schools of Architecture, New Orleans. Available at apps.acsa-arch.org/resources/proceedings. Date accessed 02/01/2018.

Giddens, A. (1985). The Nation-State and Violence (Vol. 2). Stanford, CA: University of California Press.

Giddens, A. (2013). The Consequences of Modernity. London: John Wiley and Sons.

Gilpin, R. (2011). Global Political Economy: Understanding the International Economic Order. New Jersey: Princeton University Press.

Giovannoni, E. and Fabietti, G. (2013). What is sustainability? A review of the concept and its applications. http://www.pmir.it/fileCaricati/1/Giovannoni\% 20and\%20Fabietti\%20(2013).pdf. Date accessed 05/04/2019.

Glykou, I. and Pitelis, C.N. (2011). On the political economy of the state, the public-private nexus and industrial policy. Policy Studies, 32(4), pp. 461-478.

Graham, S. (2004). Post-mortem city: Towards an urban geopolitics. City, 8(2), pp. $165-196$.

Graham, S. (2010). When infrastructures fail. In S. Graham (ed.), Disrupted Cities: When Infrastructure Fails. London: Routledge.

Graham, S. and Marvin, S. (2001). Splintering Urbanism: Networked Infrastructures, Technological Mobilities and the Urban Condition. London: Taylor \& Francis.

Gramlich, E.M. (1994). Infrastructure investment: A review essay. Journal of Economic Literature, 32(3), pp. 1176-1196.

Hall, J.W., Henriques, J.J., Hickford, A.J. and Nicholls, R.J. (eds) (2012). A Fast Track Analysis of Strategies for Infrastructure Provision in Great Britain: Technical Report. Environmental Change Institute, University of Oxford.

Hansen, H., Winckler Andersen, O. and White, H. (2012). Impact Evaluation of Infrastructure Interventions. Oxford, UK: Routledge.

Hartshorne, R. (1950). The functional approach in political geography. Annals of the Association of American Geographers, 40(2), pp. 95-130.

Harvey, D. (1985). Consciousness and the Urban Experience: Studies in the History and Theory of Capitalist Urbanization (Vol. 1). Baltimore, MA: Johns Hopkins University Press.

Hassan, D. (2006). The rise of the territorial state and the Treaty of Westphalia. Yearbook of New Zealand Jurisprudence, Vol. 9, pp. 62-74. 
Held, D., McGrew, A., Goldblatt, D. and Perraton, J. (1999). Global Transformations: Introduction. Cambridge: Polity Press.

Henckel, T. and McKibbin, W.J. (2017). The economics of infrastructure in a globalized world: Issues, lessons and future challenges. Journal of Infrastructure, Policy and Development, 1(2), pp. 254-272.

Hickel, J. and Kallis, G. (2019). Is green growth possible? New Political Economy, DOI: 10.1080/13563467.2019.1598964.

Howe, C., Lockrem, J., Appel, H., Hackett, E., Boyer, D., Hall, R., SchneiderMayerson, M., Pope, A., Gupta, A., Rodwell, E. and Ballestero, A. (2016). Paradoxical infrastructures: Ruins, retrofit, and risk. Science, Technology, and Human Values, 41(3), pp. 547-565.

Hughes, T.P. (1983). Networks of Power: Electric Supply Systems in the US, England and Germany, 1880-1930. Baltimore, MD: Johns Hopkins University.

Industrial Strategy Commission (ISC) (2017). The Final Report of the Industrial Strategy Commission. industrialstrategycommission.org.uk. Date accessed 06/02/2018.

Jackson, R.H. (1993). Quasi-states: Sovereignty, International Relations and the Third World (Vol. 12). Cambridge: Cambridge University Press.

Jochimsen, R. (ed.) (1966). Theorie der Infrastruktur: Grundlagen der marktwirtschaftlichen Entwicklung. Tübingen: J.C.B. Mohr.

Johnson, D. and Turner, C. (1997). Trans-European Networks: The Political Economy of Integrating Europe's Infrastructure. London: Macmillan.

Johnson, D. and Turner, C. (2017). Global Infrastructure Networks. Cheltenham, UK and Northampton, MA, USA: Edward Elgar Publishing.

Jonsson, D.K. (2005). The nature of infrasystem services. Journal of Infrastructure Systems, 11(1), pp. 2-8.

Johnston, R. (2001). Out of the 'moribund backwater': Territory and territoriality in political geography. Political Geography, 20(6), pp. 677-693.

Kates, R.W., Parris, T.M. and Leiserowitz, A.A. (2005). What is sustainable development? Goals, indicators, values, and practice. Environment: Science and Policy for Sustainable Development, 47(3), pp. 8-21.

Krasner, S.D. (1995). Compromising Westphalia. International Security, 20(3), pp. 115-151.

Krasner, S.D. (2004). Sharing sovereignty: New institutions for collapsed and failing states. International Security, 29(2), pp. 85-120.

Larkin, B. (2013). The politics and poetics of infrastructure. Annual Review of Anthropology, 42, pp. 327-343.

Lemay-Hébert, N. (2013). Rethinking Weberian approaches to state building. In D. Chandler and T.D. Sisk (eds), Routledge Handbook of International Statebuilding. London: Routledge, pp. 3-14.

Lefebvre, H. (1978). De l'Etat 4. Les contradictions de l'Etat moderne. Paris: Union Générale d'éditions.

Mann, M. (1984). The autonomous power of the state: Its origins, mechanisms and results. European Journal of Sociology/Archives européennes de sociologie, 25(2), pp. 185-213.

Mann, M. (1997). Has globalization ended the rise and rise of the nationstate? Review of International Political Economy, 4(3), pp. 472-496. 
Markard, J. (2011). Transformation of infrastructures: Sector characteristics and implications for fundamental change. Journal of Infrastructure Systems, 17(3), pp. 107-117.

Martin, P. and Rogers, C.A. (1995). Industrial location and public infrastructure. Journal of international Economics, 39(3-4), pp. 335-351.

Massey, D.B. (2005). For Space. London: Sage.

Mbembe, A. (2001). On the Post Colony. Berkeley, CA: University of California Press.

McKelvey, B. (2002). Managing coevolutionary dynamics. In 18th EGOS Conference, Barcelona, Spain, pp. 4-6.

Moran, M. (2002). Understanding the regulatory state. British Journal of Political Science, 32(2), pp. 391-413.

Moteff, J.D. (2012). Critical Infrastructure Resilience: The Evolution of Policy and Programs and Issues for Congress. US: Congressional Research Service.

Mrazek, R. (2002). Engineers of Happy Land: Technology and Nationalism in a Colony. Princeton, NJ: Princeton University Press.

Munnell, A.H (1992). Policy watch: Infrastructure investment and economic growth. The Journal of Economic Perspectives, 6(4) (Autumn), pp. 189-198.

Neuman, M. (2006). Infiltrating infrastructures: On the nature of networked infrastructure. Journal of Urban Technology, 13(1), pp. 3-31.

New Climate Economy (NCE) (2016). The Sustainable Infrastructure Imperative: Financing for Better Growth and Development. Www.newclimate economy.net. Date accessed 03/05/2018.

Nijkamp, P. (1986). Infrastructure and regional development: A multidimensional policy analysis. Empirical Economics, 11(1), pp. 1-21.

Offner, J.-M. (1999). Are there such things as small networks? In O. Coutard (ed.), The Governance of Large Technical Systems. London: Routledge, pp. 217-238.

O'Malley, P. (1996). Risk and responsibility. In A. Barry, T. Osborne and N. Rose (eds), Foucault and Political Reason: Liberalism, Neo-liberalism and Rationalities of Government. Chicago: University of Chicago Press, pp 189-120.

Organisation for Economic Cooperation and Development (OECD) (2008). Protection of 'Critical Infrastructure' and the Role of Investment Policies Relating to National Security. Paris: OECD

Organisation for Economic Cooperation and Development (OECD) (2011). Towards Green Growth. Paris: OECD.

Painter, J. (2010). Rethinking territory. Antipode, 42(5), pp. 1090-1118.

Palan, R. and Abbot, J. with Deans, P. (1999). State Strategies in the Global Political Economy. London: Pinter.

Penrose, J. (2002). Nations, states and homelands: Territory and territoriality in nationalist thought. Nations and Nationalism, 8(3), pp. 277-297.

Rabosa, A., Boraz, S., Chalk, P., Craigin, K., Karasik, T.W., Moroney, J.D.P., O'Brien, K.A. and Peters, J.E. (2007). Ungoverned Territories: Understanding and Reducing Terrorism Risks. https://www.rand.org/content/dam/rand/pubs/ monographs/2007/RAND_MG561.pdf. Date accessed 06/02/2018.

Redclift, M. (2005). Sustainable development (1987-2005): An oxymoron comes of age. Sustainable Development, 13(4), pp. 212-227. 
Riain, S.O. (2000). States and markets in an era of globalization. Annual Review of Sociology, 26(1), pp. 187-213.

Rietveld, P. (1995). Infrastructure and spatial economic development. Annals of Regional Science, 29, pp. 117-119.

Rinaldi, S.M., Peerenboom, J.P. and Kelly, T.K. (2001). Identifying, understanding, and analysing critical infrastructure interdependencies. IEEE Control Systems, 21(6), pp. 11-25.

Rodgers, D. and O'Neill, B. (2012). Infrastructural violence: Introduction to the special issue. Ethnography, 13(4), pp. 401-412.

Romer, P.M. (1994). The origins of endogenous growth. Journal of Economic Perspectives, 8(1), pp. 3-22.

Romp, W. and De Haan, J. (2007). Public capital and economic growth: A critical survey. Perspektiven der wirtschaftspolitik, 8(Supplement), pp. 6-52.

Rose, N. and Miller, P. (1992). Political power beyond the state. British Journal of Sociology, 43(2), pp. 173-205.

Rotberg, R.I. (2002). The new nature of nation-state failure. Washington Quarterly, 25(3), pp. 83-96.

Sack, R.D. (1983). Human territoriality: A theory. Annals of the Association of American Geographers, 73(1), pp. 55-74.

Sarté, S.B. (2010). Sustainable Infrastructure: The Guide to Green Engineering and Design. Chichester, UK: John Wiley and Sons.

Sassen, S. (2000). Territory and territoriality in the global economy. International Sociology, 15(2), pp. 372-393.

Sassen, S. (2013). When territory deborders territoriality. Territory, Politics, Governance, 1(1), pp. 21-45.

Sawada, Y. (2015). The Impacts of Infrastructure in Development: A Selective Survey. ADBI Working Paper 511. Tokyo: Asian Development Bank Institute. Available: http://www.adbi.org/working-paper/2015/01/20/6526.impacts.infra structure.in.dev/. Date accessed 05/02/2018.

Schneider, V. and Jäger, A. (2003). The privatization of infrastructures in the theory of the state: An empirical overview and a discussion of competing theoretical explanations. In E. Wubben and W. Helsink (eds), On Creating Competition and Strategic Restructuring: Regulatory Reform in Public Utilities, Cheltenham, UK and Northampton, MA, USA: Edward Elgar Publishing.

Scholte, J.A. (2005). Globalization: A Critical Introduction. Palgrave Macmillan.

Star, S.L. and Bowker, G.C. (2006). How to infrastructure. In A. Lievrouw and S.M. Livingstone (eds), Handbook of New Media: Social Shaping and Social Consequences of ICTs. London: Sage Publications, pp. 230-245.

Star, S.L and Ruhleder, K. (1996). Steps toward an ecology of infrastructure: Design and access for large information spaces. Information Systems Research, 7(1), pp. 111-134.

Stilz, A. (2011). Nations, states, and territory. Ethics, 121(3), pp. 572-601.

Storper, M. (1997). The Regional World: Territorial Development in a Global Economy. Guilford Press.

Strange, S. (1996). The Retreat of the State: The Diffusion of Power in the World Economy. Cambridge: Cambridge University Press.

Taylor, A. (2013). State Failure. Basingstoke, UK: Palgrave Macmillan. 
Taylor, P.J. (1994). The state as container: Territoriality in the modern worldsystem. Progress in Human Geography, 18(2), pp. 151-162.

Taylor, P.J. (1995). Beyond containers: Internationality, interstateness, interterritoriality. Progress in Human Geography, 19(1), pp. 1-15.

Turner, C. (2018). The governance of polycentric national infrastructure systems: Evidence from the UK National Infrastructure Plan. Environment and Planning C: Politics and Space, 36(3), pp. 513-529.

Van der Vleuten, E. (2004). Infrastructures and societal change. A view from the large technical systems field. Technology Analysis and Strategic Management, 16(3), pp. 395-414.

Vollaard, H. (2009). The logic of political territoriality. Geopolitics, 14(4), pp. 687-706.

Weiss, L. (2005). The state-augmenting effects of globalisation. New Political Economy, 10(3), pp. 345-353.

Williams, M.C. (2003). Words, images, enemies: Securitization and international politics. International Studies Quarterly, 47, pp. 511-531.

Winther, T. (2008). The Impact of Electricity: Development, Desires and Dilemmas. New York: Berghahn.

World Bank (2012). Inclusive Green Growth: The Pathway to Sustainable Development. Washington, DC: World Bank.

Zartman, W.I. (1995). Collapsed States: The Disintegration and Restoration of Legitimate Authority. Boulder, CO: Lynne Rienner. 